\title{
Memory, History, and the Construction of Self in Dina Arma's Novel The Road Home (Doroga domoy) (2009)
}

\section{Lidia Zhigunova*}

\begin{abstract}
History looms large in Circassian intellectual and literary imagination as a source of anxiety, anger, and affirmation for a people who were and still are denied history, whose humanity was at once disdained and derided. Dina Arma's autobiographical novel in Russian The Road Home (Дорога домой) is a narrative of self-exploration written from the transcultural perspective of a displaced person in search of her identity. It is a novel about identity crisis and the frustrations of a person striving to capture and to define his or her identity, especially if that person was and remains a colonial person who struggles to put together the fragmented pieces of his or her shattered history. It is a novel that describes the reawakening of national memory that takes place through the process of recovering the past and the self that has been damaged by colonial encounters. In the following article, I will examine the questions: How does Arma construct and define the concept of place or home? How does it relate to memory and identity? How does Arma engage in the process of rewriting and reconstructing history and how does she articulate the ways of re-existence and transformation of one's culture and identity?
\end{abstract}

Keywords: Circassian (post)colonial literature, the road home, decolonization of memory, trauma, historical omissions, transnationality, construction of self, border thinking and being.

${ }^{*}$ PhD Candidate in Comparative Literature, Tulane University (New Orleans, USA) 


\section{Dina Arma'nın 'Eve Giden Yol' (Doroga domoy, 2009) Romanında Hafıza, Tarih ve Benlik Kavramlarının Inşası}

\section{Özet}

Geçmişte ve günümüzde toplumsal tarihi inkar edilen, ulusal varlığı değersizleştirilip hor görülen bir halk olan Çerkeslerin entellektüel ve edebi kurgularında tarih kavramı endişe ve kızgınlık kaynağıdır. Dina Arma'nın Rusça yazılmış otobiyografik romanı Eve Giden Yol (Doroga domoy), ait olduğu mekanlardan koparılmış, kimlik arayışı içinde olan bir bireyin kendini tanıma serüvenin kültürlerarası ilişkiler perspektifinden anlatımıdır. Bu roman kimlik bunalımı kavramını ve kendi kimliğini tanımlamaya ve kendi parçalanmış tarihinin parçalarını bir araya getirmeye çalışan, geçmişte sömürgeleştirilmiş ve halen de sömürge durumunda olan bir halka ait bireyin yaşadığı hayal kırıklığı ve öfkeyi betimliyor. Bu roman aynı zamanda, geçmişin ve kolonyal karşılaşmalarla yıpranmış 'öz'ün yeniden keşfi serüveninde yaşanan ulusal hafızanın uyanışını anlatıyor. Ben bu makalede şu sorulara yanıt bulmaya çalışacağım: Yazar, mekan ya da ev kavramlarını nasıl kurguluyor ve tanımlıyor? Bu kavramların hafıza ve kimlik kavramlarıyla ilişkisi nedir? Yazar tarihi yeniden yazma ve kurgulama sürecini nasıl gerçekleştiriyor? Yeniden var olma ve bireyin kendi kültür ve kimliğini dönüştürme yöntemlerini nasıl tanımlıyor?

Anahtar Kelimeler: Post-kolonyal Çerkes literatürü, hafızanın dekolonizasyonu, travma, tarih dışı bırakılmak, ulusötesilik, benliğin inşası, sınır düşüncesi ve var olma hali.

The preoccupation with loss of one's home, in both a physical and spiritual sense, and the loss of identity shared by many (post)colonial writers throughout the world found its particular expression in Dina Arma's novel in Russian The Road Home (Дорога домой) (2009). Dina Arma is a pseudonym of the Circassian writer Madina Khakuasheva, who currently works as a Senior Researcher at the Institute of Research in the Humanities in Nalchik (Russia). Her other scholarly works include Archetypes in the Literary Works of Circassian Writers (2007) and Mythological Images and Motifs in Literature and Art (2014). Released in 2009, The Road Home is Arma's first and the only literary work, which sold a thousand copies and to date has not been 
re-published. Notwithstanding the sales figures, it was a great success among the broad Russian-speaking audience but it met with a very sparse critical response from the scholarly community, which could be attributed to either the inaccessibility of the novel in any language other than Russian, and/or the small number of copies released and sold. In Russia, however, the dearth of scholarly response could also be caused by a lack of interest in post-colonial narratives and in themes that highlight the destructive nature of colonialism, and would require a complete re-evaluation and re-examination of the legacies of the Russian/Soviet imperialism. Such revisions would inevitably clash with the "official" version of history currently maintained and cultivated by the Russian state.

Arma's novel explores the troubled relationship between history, memory, place, and the self and addresses the paradigmatic condition of "uprootedness" of Circassians. The quest for "home" and the dialectic of belonging and unbelonging expressed in the novel is linked to the quest for personal and cultural identity. This search for self-definition and for the location of a "home" is presented in the novel as a "journey," activating thus a whole range of concepts such as displacement, migrancy, homelessness, border dwelling, and the position of in-betweenness that undermine the fixity of "centers" and "margins," as well as the ideology of a unified natural/cultural norm.

The history of displacement of Circassians began in the eighteenth century with the advance of the Russian Empire into the North Caucasus, reaching its peak in the second half of the nineteenth century with the complete colonization of Circassia. ${ }^{1}$ The consequences of this event were catastrophic for Circassians, leading not only to the loss of their native land and to the breakdown of traditional social institutes and ways of living, but to their decimation and mass deportation to the Ottoman Empire. This history of dispossession, dislocation, and alienation in different forms have defined and still continue to define the existence of Circassians, both those who live in diaspora all over the world and those who remain in their homeland in the Caucasus. The imperial condition, under which Circassians continue to live even today, strips them of their native history and language as the most vital ways of transmitting and regenerating new knowledge. The current anti-Circassian policies in 
Russia eradicate the remnants of Circassian culture in what is left of historical Circassia and neglect all appeals from Circassian diaspora to give the right to those Circassians who want to return to their homeland. Seteney Shami points out that there is no homogeneous, unified conception of a Circassian identity today, even among those who live in the Caucasus: "The homeland that the Caucasus presents to its diasporic descendants is itself a fragmented and contested terrain. Circassians within the Caucasus are scattered, divided by borders, interspersed with other ethnic groups and have experienced successive displacements and exile" (Shami 1998, 631). Circassians living both in the homeland and diaspora have gone through painful but ultimately transformational interactions with and adaptation to, different cultures. This long history of displacement that formed and transformed the Circassian identities complicates the notions of home and exile, of self and other (Shami 2000, 191), contributing, ultimately, to the creation of new transnational identities.

The haunting past is still very much present for Circassians forcing them to relive all sorts of trauma associated with Russian/Soviet imperialism: the Russo-Caucasian war and mass deportations, the Socialist Revolution and the Stalinist purges, which destroyed the newly-formed national elites, the loss of their home, language, and identity. To sum up my point, I will quote David Chioni Moore who, assessing the condition of the North Caucasus and other post-Soviet locales in 2001, stated that the coloniality of these places is "hardly "post" (Moore, 115). More than a decade later, the "official" postSoviet discourses within Russia still have not reassessed in any significant or meaningful way the imperial legacies of Russian/Soviet modernity and their impact on the colonized peoples at their borderlands.

This task, however, is performed by the literary and cultural productions of the colonized subjects and their postcolonial inheritors who are concerned with recovering an identity, fragmented, displaced, and discredited by colonialism. By addressing the questions of history, memory, place, and the self, Circassian writers make an effort to reconstitute the cultural and national identity damaged by the colonial experience, to "bridge" the gap between the past and the present, to reconnect with the ancestors, and to re-imagine the 
Circassian cultural and national identity. ${ }^{2}$ They attempt to retrieve and make accessible the historical knowledge that has been censored and distorted by the Soviet modernity. This process is driven by the demand for self-respect and self-representation without any ideological limitations and state censorship. Particularly interesting in this regard is literature written by women writers, not only because of the centrality of women and their experiences, notably the search for identity, in their works, but also because this search is conveyed more deeply and forcefully than previously through the use of such genre as the autobiographical novel that contains a significant amount of autobiographical information. ${ }^{3}$ The need for self-identification, selfdescription, and self-definition comes also from the fact that Circassian women, have been for a long time objects of study and representations by others, mostly male authors. And, the instances when they did represent themselves - told their own stories in their own voices, as part of the oral tradition, have been muted or erased. Another distinctive feature of literary works written by women writers is their use of subversive techniques and multiple transgressions as they try to revive the erased histories and silenced resistance voices. For them, writing becomes "an act of resistance, as well as an act of survival, and re-existence" (Rich, 18). Their way of looking at the world from the transcultural perspective of a displaced person lies at the heart of their achievements.

Dina Arma's The Road Home is a narrative of self-reflection and self-exploration. It is narrated in the first-person by the author/protagonist Dina, a well-educated woman and a medical doctor, who aspires to be a writer. The plot of the novel is very intricate: the action takes place during the late 1980s - the transition period from the Soviet to post-Soviet state - but Dina's recollections of her childhood and the rediscovery of her family's archive takes us back to the Stalinist and the post-war periods, and even further back in time by recounting the history of her ancestors. The carefully hidden family archive rediscovered by Dina contains the personal diary of her late aunt Teun and some "documents" on Russian colonization of Circassia "smuggled from the archives in Turkey" in the 1930 s present a radically different view of Circassian history than that found in Soviet textbooks. Thus, memory and history become 
central themes in Arma's novel whose major task is reclaiming the self and the past by getting rid of erasures, omissions, fabrications and stereotypes created by Russian/Soviet historiography. Other major themes of the novel, such as the concepts of "home" and "homelessness," of memory loss and giving memory a home are closely connected to the process of recovering the self by unearthing the feminine voices in the novel. These voices, working from within the parameters of patriarchal/imperialist discourses, destabilize these discourses and end up creating new ways of reimagining the past, the present, and the future, as well as new ways of organizing knowledge and constructing Circassian identities.

Arma's novel represents a new vision and a new subjectivity that no longer simply recycles old imagery - the ways in which Circassian men, and especially women, have been constructed in imperialist and nationalist discourses - but makes an attempt at deconstructing, subverting, and transcending the dominant structures and narratives of patriarchy and empire. The power of Arma's novel lies in its narrative style that harmoniously assimilates oral and literary modes of narration, as much as in its uncompromising messages against colonial injustice. By combining autobiography with historical narrative, poetry, fantasy, and myth, Arma transgresses generic boundaries and creates a hybrid literary form. While she caresses each word and image with affection, emphasizing its magic potency, her writing style is marked by captivating lyricism and metaphoric imagery. Arma writes in Russian and, in doing so, appropriates the language of the dominant culture as a means of transforming the dominant conceptions, clichés, and ideologies that have circulated for quite some time. Most importantly, she embodies the ambivalent insider/outsider position, the so-called "threshold position," which is reflected in her writing marked by "transitional, in-between spaces where new beginnings and unexpected combinations can occur" (Keating, 2). According to Keating, this threshold position can be a dangerous and uncomfortable location for both readers and writers, because it marks the "crisis points, spaces where conflicting values, ideas, and beliefs converge, unsettling fixed categories of meaning" (Keating, 2). By incorporating this threshold perspective into her 
novel, Arma simultaneously challenges and expands the existing definitions of ethnicity, gender, race, and modernity.

In my analysis of Arma's novel, I will draw on Gloria Anzaldúa's conception of border identity and border problematic, as well as on the theoretical framework presented by the decolonial scholar and writer Madina Tlostanova. In her book Gender Epistemologies and Eurasian Borderlands (2010), Tlostanova discusses the complex histories of imperialism in the Caucasus and Central Asia through a decolonial feminist lens, and addresses the absence of these places in currently constituted postcolonial discourses. In Tlostanova's work, such concepts as coloniality of gender, power and knowledge, as well as trickster subjectivity, border thinking and being, emphasize more transcultural models and experiences of people living in Eurasian borderlands, and therefore, to my mind, are very useful for an analysis of Arma's novel. Looking at the main historical and contemporary intersections of gender, race, religion, and body in the Caucasus and its position within the cultural imaginary of the Russian / Soviet empires through a decolonial feminist lens, Tlostanova emphasizes the importance of seeing the "distortions in the Russian variant of Orientalism and the forms of resistance it has generated, linked with the fact that Russia has been a secondary empire of modernity marked with external imperial difference while its colonies have been of a doubly or multiply colonized status which has led to a specific multiplication of colonial identities and interaction vectors" (Tlostanova, 2010: 64). Therefore, as Tlostanova further maintains, we see more instances of subversion and manipulation of the imperial discourse in the Russian colonies. The most interesting of those instances, as she maintains, is "a particular impulse of gender tricksterism as a way of transcending the limitations of colonialist, orientalist, ideological, cultural, religious, ethnic, and sexual nature, and a way of acting beyond and around the dominant power structures, weakening them from a particular gendered exteriority" (Tlostanova, 2010: 66).

I concur with this idea and demonstrate in my analysis that Arma's novel is populated with characters who move across multiple boundaries. Most notably, these are the female characters who successfully engage in these transgressions. Dina, the main character 
of the novel, for example, transgresses various borders: geographical (center - periphery), cultural (dominant culture - indigenous culture), as well as historical (the reconstruction of one's past through the archival documents) as she playfully juggles her multiple identities, embodying a true trickster subjectivity who refuses to be framed in one particular context, and displaying an identity in (trans)formation. Another important point of departure in Tlostanova's work is her statement that female identities in the former and present Russian colonies "may become the source of other concepts, epistemologies, and ways of survival and re-existence" (Tlostanova 2010, xix). By practicing "border thinking" and by "being the border," these women resist the categories imposed by Western/Russian modernity, and attempt to revive other models or systems of knowledge discarded by modern imperial epistemology. In other words, they possess the "border sensibility" and the "epistemic advantage of the border" that are necessary in order to delink from the rhetoric of modernity and build bridges to transmodern epistemologies. As my analysis presents, Arma's narrative introduces the reader to several female characters that embody this resistance and take part in the revival of indigenous cosmology in several ways - some of them are unexpected and completely non-rational. As Dina recovers her female ancestors' voices (her grandmother's narratives, her aunt Zhanos's voice, and her aunt Teun's diary), they strengthen her own voice, and come to represent a narrative history and memory, previously lost and undocumented.

The loss of one's past, of history, of heritage, of language, and the painful reconstruction of the past and the self forces individuals to stand in relation to the past and the present at the same time and to look for creative means of incorporating different modes of selfrepresentation. The background and family history of the many characters that populate this novel serve as a major theme in this multi-episodic saga, establishing cause-and-effect connections between past and present. Memory is a recurring theme in Arma's novel. The colonization of memory that has produced the condition of memory loss affected generations of Circassians who were denied their history and their sense of national pride. It has been created and maintained by historical falsifications and the omissions of 
Russian/Soviet historiography, as well as by the severe censorship practiced during the Soviet regime that made any effort to expose the truth impossible. Drawing strength from a part of tradition, a part of cultural mythology and native female cosmology, Arma's protagonist makes an effort at decolonizing memory. The novel is constructed as an excavation below our conventional sight level to recover the veins of myth and memory that lie beneath the surface. The excavation process begins with the familiar, digging down through layers of memories and representations.

\section{1. "Torn Between Dream and Reality": Searching for Home in the Space of In-Betweenness.}

The borderland identity is a nomadic identity - living at the borderland means going back and forth, crossing multiple borders. It involves all kinds of journeys - geographical, psychological, linguistic, and epistemological. In her book Borderland/La Frontera, Gloria Anzaldúa describes her own experience and the experiences of women who inhabit "the spaces between the different worlds" thus:

I am a border woman. I grew up between two cultures, the Mexican (with a heavy Indian influence) and the Anglo (as a member of the colonized people in our own territory). I have been straddling that tejas-Mexican border, and others, all my life. It not a comfortable territory to live in, this place of contradictions... However, there have been compensations for this mestiza, and certain joys. Living on borders and in margins, keeping intact one's shifting and multiple identity and integrity, is like trying to swim in a new element, an "alien" element. There is an exhilaration in being a participant in the further evolution of humankind, in being 'worked' on (Anzaldúa ,18).

And, later she writes: "I had to leave home so I could find myself, find my own intrinsic nature buried under the personality that had been imposed on me" (Anzaldúa, 19). Similarly, Arma's heroine embodies this borderland subjectivity that vacillates in a space of inbetweenness, and the journey (the "road") becomes the central image of Arma's novel representing the links between past and present, as well as between motion and identity. 
The Road Home begins with Dina's return from her hometown in the North Caucasus to Moscow, from the periphery to the metropolitan center of the Soviet empire, where she studies medicine and lives in a dormitory for medical students: "I returned to Moscow on one of the blue warm August evenings" (Arma, 3). The first chapter titled "Moscow," in fact, describes a few such "returns," including back to her hometown, and gives the reader an impression of the unsettled nature of her journeys back and forth between the two locales and the instability of the concept of "home." In neither of those locales does Dina feel "at home," she experiences feelings of "estrangement" and "alienation:"

A strange feeling that has no explanation, not even a name lodged inside of me, and made me feel as if I lost something very important, but at the same time, something that was unknown to me. Vague images of dreams born in the quicksand of the unconscious were interrupted and erased by awakening; they managed, however, to stain the whole day with their colors, and I found myself torn in the space between dream and reality (Arma, 30).

Back in her hometown, in the small provincial city at the outskirts of the Soviet empire, Dina feels "out of place," "a stranger and a native at the same time," as she admits, not only because of her poor knowledge of the native Circassian language, but also because of her "deep longing" for something "significant and bright" that was lost beneath the layers of lies and distortions. The apparent happiness and vitality of the "standardized" Soviet reality in her hometown depress Dina, as she begins to feel "tormented by vague emptiness and heaviness that hung in the surrounding atmosphere" (Arma, 160). Dina noticed quite early that reality had been substituted with a Soviet myth, an invention that was carefully cultivated in the minds of people and to which they feverishly tried to adjust. This realization made her different from other natives who seemed to be quite happy with their existence, living in a state of "blissful obliviousness" and spending their time engaged in "primitive intrigues." Rejecting this world and its "truths," Dina spends most of her time reading books, and escaping into different worlds. 
Significantly, the novel begins with the protagonist traveling from the periphery to the center, emphasizing Dina's attraction to Moscow as yet another point of escape, and as a multicultural space where she hopes she will be able to resolve her identity crisis. Moscow with its "motley crowd of a big city, where most people lost their roots or any lasting attachments" (Arma, 42) promised to become a new home to Dina. In addition, Moscow as a space of intense transcultural exchange and knowledge production, offers to Dina, who yearns for knowledge and experience, an opportunity for professional development as a medical specialist and as an aspiring writer. The dormitory, Dina's place of residence in Moscow, reminded her "more of a fortress than a house." At first, it seemed "friendly and homelike" (Arma, 30). At the same time, however, this place with its elevator doors closing behind her with "heavy metallic clang," as if it was the "last evidence" of her "final isolation from the outside world," gave her a frightening impression of being a "prisoner" (Arma, 30). Dina's comparison of her dorm to a "drifting ship" further intensifies the shaky nature and the instability of her new home, creating a feeling of in-betwenness. On the one hand, in Moscow, Dina feels at home like "a fish in the water," but on the other hand, as Dina admits, "a great part of me remained unacknowledged and in a dormant state, presenting a mystery to myself and to others" (Arma, 59). Dina's roommates and fellow-students barely knew who she was and tried to put various "labels" on her, defining her as a "product of hybridity resulting from the melting of various cultures" or as an "international" or "above-national" phenomenon. Dina, however, who always found those abstractions "absurd," resisted such oversimplified labeling that put her nicely into a box, and most importantly, concealed her story and her history:

I was prepared for this kind of labeling that identified and defined my weakest link, the subject of my painful searching in the labyrinth with an idiotic sign: "Who am I?" How can I explain this feeling of alienation that prevented me from feeling at home anywhere I went? (Arma, 58)

Arma's heroine always wonders and tries to understand who she is; she is constantly invaded by a sense of unbelonging, the feeling 
that she never belongs anywhere, but at the same time can feel at home in many places. She embodies what Tlostanova calls a "true trickster identity" that has evolved at the borderlands of the Soviet empire, an identity that is often marked by "migration, lack of roots, a paradigmatic unhomeleness, loneliness, and otherness at any place, yet at the same time, an ability to flexibly adjust to any space, acutely reacting to its signals and resonating in response" (Tlostanova, 2010: 147). The conditions of "homelessness" and memory loss, as well as the lack of positive self-identification, which were the product of Russian colonialism and which the main character of Arma's novel struggles with, were further intensified by the Soviet imperialist ideology that, on the one hand, emphasized "internationalism" and "friendship" among the ethnic groups, but on the other hand, marginalized or completely silenced them by falsifying or denying them their history and identity. Tlostanova relates to this issue by describing the condition of "homelessness" that her generation has experienced as a "globalization narrative of seemingly erased boundaries:"

Home has become very early a virtual concept for us and any links with it are extremely complicated. We are dispersed around the world and the past for us often shrinks into a thin pack of discolored photographs, a couple of old objects and a few memories and old histories. Yet we strive to retain it - that transient elusive sense of community and continuity based on the urge to keep one's dignity, honesty, and decency, to never be a victim or a beggar, and to remember that each of us has her own task in life which she must discover for herself, understand and fulfill (Tlostanova, 2010: xvii).

Dina's search for home is one of the driving forces that set her off on a journey to retrace her steps, her culture, her heritage and her self.

Dina's dormitory also signifies a multiethnic Soviet space shared by all members of an international "family," consisting of an African man, a German girl, an Uzbek, an Evenk from Siberia, and a few Russians who comprise a Muscovite variable of "Russian" identity. Dina, who comes from a family of Soviet national intelligentsia, seems to be well-adjusted to her life in Moscow; nonetheless, she remains a 
marginal exotic variant among other exotic characters. Arma portrays Moscow as a space of transcultural encounters, but with a strong dominance of Russian culture, exposing the asymmetrical power relations existing between the center and the periphery.

Dina feels closer affinity between her and other colonials, such as, for example, the Uzbek man named Chary, with whom Dina never spoke a word, but felt that there was a "mutual understanding" existing between them (Arma, 44). Unlike others, Dina also never felt awkward in the presence of Toi, one of her admirers of African descent, who would usually sit in her room and stare at her for hours without uttering a word. Despite the fact that the feelings were not mutual, Dina let him engage in this activity. Once, after he had left, Dina stared at her own reflection in the mirror examining her face: "looking closely into the darkness of pupils," she wanted to discover something "immense and unknown" (Arma, 32). At that moment, Dina saw the appearance of "a strange woman with a dark face and a calm smile on her full lips whose piercing eyes were filled with inescapable melancholy" (Arma, 32) staring back at her in the mirror. This episode is very revealing in the sense that the mirror as a medium of self-understanding and self-reflection may be understood as a metaphor for the appearance of the quest for self. The image of the African woman as Dina's reflection of herself embodies a confrontation with the other, which also represents for the protagonist the mirror-stage of the self. And, this "identification" between the subject and its reflection may be seen as an expression of the oppressed mind and self.

There are many other instances of transcultural encounters in the novel. One of them is, for example, Diana's acquaintance with Sasha, a medical student from Orenburg whose parents were Evenks from Siberia. Sasha slowly opens up to Dina and shares his memories of his family and his tragic past. The significance of Sasha's story lies in its exposure of the repressive Soviet policies towards the non-Russian imperial subjects. From their conversations, we learn that as children, Sasha and his sister were forcibly removed from their parents by the Soviet state authorities and put into a boarding school simply because their parents were nomads - just like their ancestors before them, and which had been their people's way of life for centuries. As Sasha 
explains, this has been done to all "children of the North," in order to prevent them from continuing their ancestor's "savage" way of life and to ensure their acceptance of the "civilization" that Russia brought to them. Speaking in his own voice, Sasha shares his thoughts with Dina:

I don't understand, how could one settle down and pursue agriculture and farming in the tundra where it is only warm three months in a year!...And, then some people came and started to drill holes for oil extraction. The locals did not get anything for the extraction of their own natural resources; all the money went into the pockets of people standing behind those corporations. They have destroyed the entire ecosystem of the region... (Arma, 5)

Sasha's narrative sheds light on the destructive nature of Russia's conquest of Siberia, another unacknowledged and distorted history, and represents an extreme case of lost cultural identity. Dislocated in both the physical and the metaphorical sense, these people have become the object of "cultural denigration" ${ }^{4}$ - they had to abandon their land, their communities, their traditions, religions, and languages; they had to give away their roots and their real names. By incorporating Sasha's story into her novel, Arma gives voice to those who have been marginalized or completely silenced by the dominant Soviet ideology. Sasha continues:

Only recently, I came to the conclusion that we all became hostages of a very ugly and corrupt state system; we witnessed the destruction of the centuries-old way of life of the peoples of the North. Almost all children of my age were taken away from their families. Gradually, they lost their connections to their parents and other relatives; they have lost the ability to hear and understand the taiga, their natural environment, to hunt and to breed reindeer, to migrate with them accompanied by dogs. I completely forgot my native language. Some of us became scientists and a small national intelligentsia was formed...But at what price! Almost all of us became stepchildren of the North that never forgives the violation of its law, the law of nature. People were trying to save themselves from this horrifying sense of emptiness and confusion....any way they could, but mostly with the help of alcohol and drugs. In this way, several generations 
were uprooted and lost forever. For the most part, people drank themselves to their deaths; others, like me, left the place and came here to Moscow (Arma, 6).

Thus, we learn about the erased histories of the peoples of the North whose ancestral way of life and whose traditions have been disrupted or completely destroyed. Sasha's story introduced at the beginning of the novel shatters the illusion of normalcy and happiness in this multiethnic Soviet family and triggers Dina's search for her own identity and ancestral history. It also sets the tone and prepares the reader to learn more about the tragedies and atrocities perpetrated by the empire against other members of this "happy" multiethnic family.

As Dina tries to put together the puzzle of her family's and her nation's history, it proves not to be an easy task because of many missing or erased pieces and sweeping misrepresentations. The rediscovered "family archive" helps her to uncover the "forgotten" pages in the history of her own people and to fill in the voids in her memory. Rejecting the notion of assimilation, as well as the mythic rhetoric of nationalist exclusiveness, Arma's new humanistic approach in her decolonial writing is based on an ethics that acknowledges differences in identity and history. The Soviet doctrine of assimilation only succeeded in denying the colonized their historical agency and in the loss of their unique culture. Similar ideas are presented by the decolonial writer Madina Tlostanova who emphasizes that the decolonization of knowledge and mind is the only way out of dehumanization in which the colonized live. Tlostanova argues that Western and Russian modernity is responsible for these ideological distortions through which "the whole histories of peoples were erased and rewritten depriving them of any links with the past and methodically eliminating any subversive sources linked with passive and active resistance to colonization and re-existence, and being in spite of everything" (Tlostanova, 2010: 170). During the Soviet period, as Tlostanova notes, "the indigenous peoples were brainwashed with the idea of their own presumable backwardness and the false belief that only the Bolsheviks (Russians) allowed them to make a leap from medieval times into socialist modernity, or even from the cavemen to the communist future..." (Tlostanova, 2010: 170). 
Tlostanova further maintains that the idea of creating hybrid Soviet citizens by erasing the differences between the colonizer (Russian) and the colonial people (non-Russian) based on the equality of all Soviet citizens was racist from the very beginning, because it meant an assimilation into imperial Russian culture by which all Soviet colonials were forced to study Russian language, Russian history, Russian literature and completely ignore their own language, culture, and history. They were forced to change everything about themselves, the way they dress, what they eat, how they wash themselves, etc. (Tlostanova, 2010: 140). Their culture and their dress was then reduced to highly artificial creations in the forms of national dancing ensembles and national literature written in a form allowed by the Party style of Socialist Realism. Tlostanova notes that the result of such "liberating" and "modernizing" efforts on the part of the Soviet empire was the creation of "second-rate colonial Soviet individuals" and the production of the most powerful myths that persist even until today in the minds of both metropolitan and local cultures, strengthening the imperialist tendencies of the former and the "self-orientalizing" of the latter:

In reality the Soviet "liberation" often came to a nominal change of clothes and no less nominal Russian/Soviet style primary education that colonized rather than liberated the minds, left them ignorant about their own cultural tradition or history, epistemic or linguistic legacy, and effectively zombified both men and women, creating a specific self-orientalizing inferiority complex, compensated with heroic efforts to modernize as quickly as possible. The selforientalizing of the local population has become one of the major successes of the Russian/Soviet colonization which made the colonial subjects internalized the once alien values and standards (Tlostanova, 2010: 140).

According to Tlostanova, this spiritual colonization or zombification turned out to be "worse than economic exploitation or even genocide" (Tlostanova, 2010: 170). As a result of the Soviet modernization, "even the smallest traces of indigenous cosmologies and ethics were irreparably erased from the collective memory and 
replaced with either Soviet Eurocentric progressivist discourse or today - with ersatz ethnic nationalism" (Tlostanova, 2010: 171).

The successful "zombification" of the local population was the outcome of extended subjugation resulting in compensatory behavior by the subject peoples who sought to mimic the dominant cultural forms. One of the manifestations of this behavior is the indifference of the natives to their own history and cultural traditions that were perceived as obsolete and worthless. This condition is represented in Arma's novel in the episode in which local librarians burned old rare books on Circassian music and folklore. Dina, who witnessed the burning of books at the library of one of the local villages, was able to pull from the fire one book entitled "The Anthology of Circassian Instrumental Music." Close to tears, she asked the librarians: "Why did you burn this unique book?" Their answer was: "What else could we do? Nobody checked out this book in ten years. It is sitting on the shelf and gathering dust. We relocated it several times from place to place, but now other libraries refuse to take it as well." (Arma, 169170)

The lack of memory and the emptiness or the oblivion it creates where there is no association with image, color, scent, and sound is a major source of marginality. Recognizing the importance of these connections, Arma's novel makes an effort to reconstruct these associations by going down memory lane to the places of her protagonist's childhood. Part two of the novel titled In the "City of Happiness," takes the reader to a few such places back in her native town that are represented as "special" and "magical" - her grandmother's apartment in the city where Dina spent the "happiest moments" of her childhood and the old family house in the village. Unlike their "tiny and faceless apartment" in the city, where Dina lived with her parents, the grandmother's apartment was a unique place associated with happy memories, light, and harmony:

It seemed to me a special place, primarily because of the atmosphere that filled the entire space. Its strict, almost ascetic interior unfettered and awakened my imagination and determined its direction... It [the grandmother's apartment] was light...the coziest island in the warm clear waters of my childhood (Arma, 108-114). 
Dina was very close to her deeply religious yet independent grandmother, closer even than to her mother whose generation has been directly affected by the Soviet policies of the emancipation of women. Dina's grandmother never tried to control her granddaughter's behavior and looks or discipline her in any way. At the same time, she secretly taught her to pray in Arabic and told her stories that reflected a different ethnic-cultural world view and value system that emphasized spirituality, sensitivity, and harmony as opposed to the harsh pragmatism and realism of Russian/Soviet culture. Deemed illiterate, this generation of grandmothers was able to escape the indoctrination with the official colonial version of memory and still retained the traces of other epistemic models and forms of knowledge. Dina's grandmother who was the "center and the beginning of life" (108) was the keeper and the transmitter of the traditional wisdom. The grandmother's voice, her stories and tales transmitted orally to her granddaughter, becomes an important instrument of recovery of indigenous cosmology and epistemology that have been distorted and muted by Russian/Soviet modernity.

In her novel, Arma highlights the importance of oral traditions in comprehending Circassian history and culture by weaving various folklore materials into the fabric of her novel. In doing so, she also recovers the voices of the natives that have been muted and marginalized. Two such examples are the inclusion into the novel of the nineteenth-century lament-song "The Destruction of the Village" describing the massacre of Circassians by the Russian colonial army, and a very somber "Lullaby Song" from the same period (Arma, 234). The recovery of these voices and sources of knowledge that have been completely marginalized by Western/Russian modernity's emphasis on the primacy of the written tradition is one of the keys to recreating the self and the unity of the indigenous world.

In the chapter The Old Manor, Arma's heroine, haunted by her "longing" for local color and flavor, revisits the old family house where she rediscovers these vital connections to sound, image, and scent, and finds her aunt Teun's personal diary along with some important archival documents that throw light on her family's and her nation's tragic history. Dina's return to this house is one of the most important journeys in the restoration of her sense of place and 
belonging, as well as in the reconstruction of the history of her family and her people. Located in the nearby village, the old manor, where Dina spent the "best days of her childhood" (Arma, 180), encompassed the old ancestral house, the large garden that resembled a forest, and a stream running through the whole garden. The house that was once "the favorite place for family gatherings" and that was still connected by the invisible memory threads to the extraordinary history of her family and the once strong spirit of her nation "now stood abandoned and half-forgotten." Dina describes how over the years, she witnessed the "steady decline of the house, in which people once spoke their own native language" and celebrated their own festivals marking the most important events on the agrarian calendar of Circassians - Winter solstice Dyghaghaze and the Spring equinox Mafashkhadzhed (Arma, 194).

Going down memory lane, Dina recalls the old ancestral house and the garden as she experienced it as a child being a "magic place" filled with fragrant smells, flavors, colors of beautiful plants and trees, where people understood the language of nature. It was a place where every plant was known and cherished for its beauty, as well as for its healing and nurturing qualities. Describing the old ancestral house as a place where nature and people coexisted with each other in a complex spiritual and physical continuum, Arma attempts to reanimate the holistic view of the world that has been an integral part of Circassian culture and cosmology in the pre-colonial period. References to ancient Circassian gods and goddesses in the novel such as the god(dess) of forest Mazytxa ${ }^{5}$ and the goddess of water Psykhuaguashe, as well as to the supreme Circassian god $T k h a^{6}$ serve to renew the links with indigenous spirituality and emphasize the idea of responsibility for maintaining the "dynamic equilibrium" between nature, people, and gods that was part of the belief system of the natives. This view was also expressed in a particular ethical code and a system of rules and etiquette called Adighe Khabza demonstrating the "oneness and unity of religious and social spheres and the importance of keeping the cosmic balance at all levels" (Tlostanova 2010, 164). The radical erasure of the indigenous cosmologies and epistemic systems by the Soviet modernity led to the loss of faith that was rooted in indigenous attributes, images, symbols, magic, and myth, 
damaging in the process the spiritual balance and the dynamic equilibrium that existed between man and nature, and between the sexes. ${ }^{7}$

Dina's aunt Zhanos, who is the only surviving inhabitant of the house and Dina's connection to the past, is represented as someone who tries to restore the lost equilibrium. Zhanos, just like Dina's grandmother, was the keeper and the transmitter of the family's history: "Thanks to Zhanos and my grandmother the mighty crown of our family tree that has been growing extensively was kept alive and constantly recreated" (Arma, 187). For Dina, Zhanos was a "personification of Mnemosyne" whom she followed as an "Ariadnes' thread in the endless labyrinths of the past" (Arma,187).

Zhanos, who refused to sell the house and relocate to the city, is represented not only as the keeper of the house and the family history, but also as a traditional healer whose knowledge of plants combined with other esoteric practices helps to heal sick people:

Zhanos collected herbs in the spring, summer and fall and after drying them out, she used them for healing purposes. Until late autumn, Zhanos was busy making infusions and decoctions that she handed out to sick people who came to her in a sparse, but an endless procession. She did not take any money, considering it a sin (Arma, 200).

The importance of women-healers to the restoration or the healing process of the indigenous spiritual legacy that has been distorted, suppressed, and partially erased by the Soviet modernity has been suggested by Tlostanova. She notes that these women, uneducated in the Western sense, possessed an "enormous power inherited and learnt from their ancestors" (Tlostanova 2010, 166). According to Tlostanova, maintaining traditional practices, esoteric, and non-rational forms of knowledge, often of pre-Islamic origin was one form of resistance to modernity, since these practices and forms of knowledge were "completely inaccessible to (and thus uncontrollable by) modernity" (Tlostanova, 2010: 174). In addition, as these women attempt to "escape the bondage of modernity," they stress the importance of individual spiritual growth and completely ignore the material side (Tlostanova, 2010: 174). Thus, Tlostanova 
argues, these women, who attempt to negotiate various forms of modernity and indigenous spiritual legacies, constitute true examples of "gendered colonial tricksterism" and embody a border identity in its outmost trans-epistemic sense (Tlostanova, 2010: 166).

In the novel, both, Zhanos and grandmother, represent the links to the indigenous cosmology and epistemology buried under multiple layers of imposed ideologies. Unearthing the feminine voices of Zhanos, of the grandmother, and of Teun whose diary Dina found at the old family house strengthen the voice of Dina herself. The powerful images and voices of women in Arma's novel are designed to restore the strength of the female element that has always been part of the indigenous Circassian cosmology. Filling an existing void, they come to represent the lost and undocumented narrative history and memory.

Another painful loss that is articulated in the novel as a disorder or trauma is the loss of the native language. During her trips to the village, Dina describes herself "painfully suffering from bouts of linguistic deficiency" (Arma, 193). The native Circassian language was banished from the Soviet school curriculum and work places, and although it had a status of the official language, Russian was imposed as the language of instruction and communication, and Circassian was marginalized and pushed out to the peripheral spaces:

After the Russian-speaking kindergarten and the school, where the native language class was optional and elective and we missed it at every opportunity without even being penalized; after the Russianspeaking institutions in which my parents worked forcing them automatically switch to Russian; after all the university courses taught in Russian, this was the only island of undiluted native speech, to which I had become almost completely unaccustomed since the death of my grandmother (Arma,193).

Dina was fully aware of the consequences of such policies ${ }^{8}$ that robbed her of the freedom of thinking in her native language, seriously damaging the link with the local value system and knowledge. Metaphorically, the old family house now stands for the half-forgotten native language, traditions, and history and currently 
occupies the place of in-betweenness; isolated from the rest of the world, it remains in an uncertain, irresolute state:

The late autumn fog disconnected our house from the outside world, it muffled all sounds as if the surrounding objects were licked off by a giant animal or the land itself became a mythical monster who forgot to breathe and exhale the visible space, it made the house look as if it was hovering in a ghostly nothingness... (Arma, 200)

But, significantly, it was Zhanos, the woman-healer, who guarded this space and tried to breathe life into it. In the novel, she symbolizes the presence of the strong women's element that is still alive and that has been characteristic of Circassian society. Both, Zhanos and grandmother could be seen as surviving links to the indigenous epistemic models that manifested "feminocratic traditions, gender egalitarianism, and lack of fixed gender divisions" (Tlostanova,2010: 164). According to Tekueva, traces of such models are to be found today mostly in Circassian mythology and folklore, where we see the presence of powerful female deities, and in the tradition by which older women still enjoy enormous power and respect by all members of society (Tekueva 2006, 10). The erasure and the disappearance of these traces of indigenous cosmologies led to the intensification of patriarchal tendencies in Circassian society - not only were the powerful female deities substituted by male deities, but also the "feminocratic traditions" were replaced by male-centered culture that favored the subordination of women, and occasionally, even perpetrated violence against them.

There are also male characters in the novel that possess certain esoteric qualities, most notably the "flying characters" such as Dina's uncle Leva (Liuan) who has the ability to "levitate" and their neighbor Aslan, who "was falling out of the house, both literally and figuratively" (Arma, 124). The supernatural qualities that these characters possess mark them as unconventional, not ordinary, falling out of the Soviet reality, which emphasizes their sense of displacement and unbelonging. They both felt discontented and each, in their own way, tried to escape reality. Aslan, who lived in the apartment building of Dina's grandmother, was an artist. Aslan's sense of unbelonging to the house and to the world that he inhabits is 
vividly expressed by the author: "There was a neighbor who lived two floors above and who was falling out of the house in the literal and figurative sense. He was too great for small apartments, houses, and streets of our city, too strong for small bustling urban whirl, too majestic for the monotonous everyday life" (Arma, 124). Aslan was a musician who played the flute and sang in such a magical voice that when he sang "the entire house froze and turned into one reverent ear" (Arma, 124). But the narrator points out: "I did not, however, catch the era, when Aslan was singing" (Arma, 124, italics in original) referring thus to the loss of the ancient Circassian tradition of oral performance and the institute of dzheguako that disappeared with the advent of the new Soviet era. Aslan did not fit into this new Soviet reality, even with his appearance: "he looked like a perfect pagan deity accidentally lost in a strange world" (Arma, 124). Eventually, Aslan started to drink, and at night, the neighbors heard him crying. Once, Aslan tried to commit suicide by jumping from his apartment on the third floor, but since he "had a soft landing," he repeated his attempts several times: "Very soon these flights from the balcony of his apartment became commonplace, along with his beauty, his drinking problem, and his nightly weeping" (Arma, 126).

Both characters, Aslan and Leva, were not as successful in transgressing the borders and bridging the gaps between the past and the present as the female characters. Perhaps, the most successful of them was Mussa - Dina's husband, a Middle Eastern man of Circassian decent, after whom the entire last part of the novel is entitled. Mussa, a trans-diasporic individual whom Dina met in Moscow, introduced her to the representatives of Circassian diaspora who had "secret meetings" in Moscow. They both attended these meetings and participated in the discussions of the most urgent issues pertaining to the precariousness of Circassian situation: the loss of the native language, both in homeland and in diaspora, the assimilation process, and the repatriation issues. Dina's bonding with the representatives of the Circassian diaspora and the secrecy of their affairs signifies the beginning of the trans-diasporic Circassian dialogue that has been politicized and driven almost underground by the repressive political system. Although their marriage was shortlived, their spiritual unity was strong. Mussa, who was a religious 
man, emphasized the importance of listening to oneself and to the voice of God within oneself that will help to find the lost purpose in life, the lost equilibrium:

The biggest sin of our nation lies in the fact that we lost our God... God is looking for his people in their own land, and calls to them in the language of the people. If people have lost their land and lost their language, they cannot hear their God (Arma, 335).

Speaking through Mussa, a prototype of Messiah, Arma emphasizes the importance of the recovery of lost spirituality and the unity that existed between nature, god, and people. By exposing the existence of the "other world" and the other faith rooted in indigenous attributes, images, symbols, magic, and myth, Arma counters the "official" reality of the rational modes of representations and historical truths, as well as the institutionalized religions and religious practices. These trans-diasporic Circassian encounters that occur at the heart of the Soviet empire also testify to the heterogeneous nature of Circassian identity and to the notion of mobility that has become an integral part of this identity.

\section{2. "Where is the History of My People?"}

The reconceptualization of the history of Circassians in Russian historiography, overcoming the archival silences and absences, and withholding the "permission to narrate" became important topics in both Circassian fiction and in non-fiction literature of the post-Soviet period. Since Circassians have been excluded from the official Russian historiography and their representations have been distorted, literature reveals itself as a powerful means to recover the past, as an act of self-assertion and self-possession. The struggle for historical truth in the North Caucasus is still ongoing and manifests itself in a clash between the official Soviet/Russian version of history that insists on the "voluntary joining" of the Caucasians and the "counter memory' of historically repressed groups. Circassians, as well as other Caucasians, such as Chechens, Daghestanis, and Ingush, started to actively object to the ideologically motivated falsifications of their histories, especially with respect to their legitimate national-liberation 
struggle against Tsarist imperialism. The struggle of these groups for decolonization is centered on the politics of memory, and on questions of identity and history.

In Arma's novel, the present and the past, the personal and the political, truth and justice acquire a specific form through the use of the rediscovered family archive - the personal diary of her aunt Teun along with various documents, including excerpts from the reports of the Russian colonial administration, eyewitness accounts of the colonial officers, and various witnesses such as journalists and diplomats, that threw light on the Russian expansionist policies in the region. In the chapter The Blue Files, Arma critically engages with the Soviet/Russian version of the colonization of the Caucasus and the continuous ideology of denying Circassians their history of resistance to colonization. She presents the "forgotten" history of Circassians by including references to, and examples of, eyewitness accounts of the atrocities perpetrated by the Russian empire during the colonization of Circassia. These actions, as many historians now argue, amount to genocide. ${ }^{9}$ In addition, she explores and rebuilds the past through the imaginary - by incorporating myths, legends, and beliefs into the fabric of her novel. Returning to popular folklore, mythology, and roots is a continuous tendency among Circassian writers and artists, as is the quest for history reflected in the novel. The chapter contains Teun's diary, various archival documents concerning the Russian colonization of Circassia, reminiscences of an old family friend about Stalin's repressions, as well as two parables, narrating the myth of origin, decline, and rebirth of the Circassian nation, that symbolize the past, present, and future of Circassians.

In Teun's Diary, Arma brings to light the sincere revelations and self-reflections of Dina's aunt Teun whose short life was somewhat mysterious; she died of a heart attack at an early age. Her sudden death and the unknown story of her life tormented Dina who suspected that it might have something to do with her own search for the "truth." In her diary, Teun relates in a very emotional way her experiences upon reading the archival documents that she found among her fathers' things: 
I am just starting to see clearly. I never could understand who we are. Studying world history and the history of Russia, I was always tormented by the question: Where is the history of my people?

...Just yesterday, I did not know that all of us had been completely immersed into a vacuum, and we became people without a past and a future, some small insignificant nation without a culture, because culture implies the continuity of history. And, that continuity we have been deprived, it was taken away from us: we are a handful of survivors deprived of historical memory. We have been deprived of our thoughts and feelings; we are mimics obeying and repeating someone else's words and actions, and as such we are loved and being 'replicated.' But, those who do not fit into this framework are being destroyed... (Arma, 255-256)

Smuggled by Dina's grandfather's friend from the archives in Turkey and carefully hidden by her grandmother and aunt Zhanos at the old family house, these archival documents that filled in the existing memory voids and historical omissions brought misfortune to those who possessed them. Like most members of Circassian intelligentsia who were murdered during the Stalinist repressions, they were either killed by the repressive political regime, or without being able to rehabilitate justice by confronting the Soviet propaganda machine, they could not cope with the truth and died of a heart attack, like Teun and other members of Dina's family. This was the era when purges suppressed any voice of national aspiration, giving local power to Moscow's puppets through a number of policies including adopting the Cyrillic alphabet in non-Slavic regions; establishing the primacy of the Russian language in education and the work place, which endangered the existence of the native languages; and limiting sovereignty in the non-Russian republics, whose histories were interpreted and rewritten as narratives favoring the interests of Moscow and the dominant Russian culture.

Countering the official historical narrative of the Russian/Soviet Empire, these eye-opening accounts demonstrate the immorality of colonial conquest and the righteousness of the resistance against it. Only a few people at that time had access to the documents and knew about these atrocities. The family archive that emerged from 
"nothingness" and the fragments of memories that Dina was able to recover establishes a Circassian perspective to history and tells the forgotten history of an entire people - these are the stories of loss, dispossessions, and tragic deaths during the long years of wars, repressions, and famine that the Circassians endured. Thus, Arma writes not only the history of her own family, but also a post-colonial history that goes beyond the officially approved version of imperial histories and relates the stories and the experiences of the colonized people.

In the chapter The Documents, Arma cites the eyewitness accounts of the officers from the Russian imperial army who took part in the colonization of the Caucasus, as well as the descriptions of events provided by the Russian imperial historians whose accounts have been muted by the Soviet historiography. These narratives incorporated into the fabric of the novel serve the need for restoring, filling and correcting the official historical narrative. The inclusion of these documents also marks the beginning of the process of liberalization of archives following the dissolution of the Soviet Union in 1991. Arma re-writes history from an officially accepted, familiar narrative of Russia's triumph in the Caucasus and a willing subjugation of the natives to the Russian rule, and turns it into a narrative of oppression, dispossession, dislocation, and genocide. In her novel, Arma cites, for example, the Russian historian Eugene Felitsyn (1848 1903) who described the events as follows:

The war was fought with inexorable severity. Hundreds of Circassian villages were burned down; their crops were wiped out or trampled by horses; the residents who decided to submit were evicted to the areas under the control of our police officers, the rebels were sent to the Black Sea shore for resettlement to Turkey (Arma, 145).

According to Maja Catic, the Tsarist deportations were motivated by the logic of settler colonialism, aimed at permanently removing Circassians as competitors for land and recourses (Catic 2015, 1698). This violent incorporation of Circassian territories was intended to permanently extend the territorial jurisdiction of the Russian state over the North Caucasus. After an armed resistance of Circassians to Russian imperial conquest, which lasted a century from 1763 to 1864, 
almost all of the survivors, approximately one million, were forcibly removed from their land and deported to the Ottoman Empire. Catic notes, anywhere between $30 \%$ and $50 \%$ perished from hunger, disease or violence, on overcrowded ships or in refugee camps upon their arrival in Anatolia and the Balkans (Catic 2015, 1687). The actions of the Russian imperial state during the last phase of colonization of Circassia that led to the physical annihilation of a significant amount of population, the deportations of Circassians and the expropriation of their property prompted Circassian nationalists in the 1990s and later historians (mostly in the West) to raise the question of Circassian genocide, which is vehemently denied by the Russian state and the majority of contemporary Russian historians, despite the staggering evidence suggesting the opposite.

The genocide of the Circassians during the Russian colonial conquest which has never been openly discussed emerges as a significant theme in the novel. Here is how the horrors of the final period of Russian colonization are described by the Russian imperial officer Drozdov, who participated in the subjugation of Western Circassia in 1863-1864:

At the end of February our Pshehsky military unit moved to the river Marte, in order to observe the eviction of the mountaineers, and if need be to expel them by force. Gradually moving to the right and to the left, then up and down, destroying the abandoned villages on our way, we reached the river Psekups...On the road our eyes were met with a staggering image: corpses of women, children, elderly persons, torn to pieces and half-eaten by dogs; deportees emaciated by hunger and disease, almost too weak to move their legs, collapsing from exhaustion and becoming prey to dogs while still alive... Those alive and healthy had no time to concern themselves with the dying; the Turkish skippers, out of greed, overloaded their boats with Circassians and threw anyone who showed the slightest sign of illness overboard. The waves washed the corpses of these unfortunate souls onto the shores of Anatolia...Scarcely half of those who set out made it to their goal. Such a disaster on such a large scale rarely befell mankind... Now, in the mountains of the Kuban region one can meet a bear, a wolf, but not the mountaineer (Arma, 247-248). 
In fact, the Soviet/Russian version of the colonization of Circassia represented in the history textbooks and other official sources emphasizes that the Cossacks and other colonists settled the empty lands while never specifically mentioning the reasons why the territory became "empty. ${ }^{10}$ By incorporating these accounts into her novel, Arma reminds her readers of these crimes, because re-living these violent acts keeps the memory of violence alive and with it the hope of restoring the truth that was "lost in time;" the truth that "fled from millions of pages of books, from the TV screens, from the greedy hands and sticky eyes, from a muddy stream of words that form the rivers and seas of verbal filth, but remained as imperishable light in the hearts of nameless fallen soldiers" (Arma, 348). The inclusion of the archival documents that describe the concrete policies of Russian colonial expansionism in the region is an effort to rehabilitate manipulated and suppressed memories and to reclaim justice, but the unwillingness of the colonialist culture to accept the historical evidence demonstrates that once a political culture was constituted in which even the most severe crimes- including genocide and the wholesale exportation of the native population - remained unacknowledged and unpunished, there is nothing that keeps that culture from coming back.

After Dina discovers the archive and learns the truth, she goes back to Moscow, back to the center, and tries to call attention to this historical injustice. The chapter At the Café relates the conversation between Dina and the representative of the metropolitan culture who is described as a man with "blue eyes," a "prose writer, a real classic," and a "true representative of the demos" (Arma, 313). When their conversation touched on the subject of the history of the "Caucasian war," ${ }^{11}$ Dina "lost control and could not stop talking:"

I was speaking, releasing the layers of pain that until now had been mute and which I had not yet fully been aware of myself... I have consciously and yet in an uncontrolled way violated an unspoken taboo, perhaps simply because it had expired (Arma, 313).

Dina tried to convince her interlocutor that the time has come to rewrite the history without ideological omissions and falsifications: 
It is our fate, the fate of the current intellectuals to have the courage to face the terrible events of the past, without hiding from them, without suppressing or silencing them; fate silently demands from us that we should recognize the past for what it is and give it a real name. Our past is our shadow, or a blindfold, but it is always with us... Our burned and erased history persistently looms in front of us and requires a full and fair resolution... (Arma, 314).

She did not, however, find any understanding or any support on the part of the intellectual from the center, who condescendingly dismissed her revelations. Instead, she was reprimanded with the same colonial narrative of the civilizing mission of the Russian empire that presented the colonization of the Caucasus as an act of benevolence: "What genocide, my dear! Genocide is when the civilian population is exterminated. There are no such facts...Tsarism actually saved the Caucasus!" (Arma, 314, emphasis in the original) At this point, Dina experiences a "strange feeling of powerlessness, fatigue, and hopelessness," as she realizes the he represents the "views of the majority" that without any remorse readily reproduces the imperialist mythologies and remains ignorant about the history of the colonized peoples.

This conversation highlights the phenomenon of the "coloniality of memory" that, according to Tlostanova, exists in "post-dependence" (including post-socialist or post-dictatorship) societies, in which trauma and memory remain too often unacknowledged, "repressed and under-analyzed by the majority and hence repentance or responsibility never even come in sight" (Tlostanova, 2014: 64). Tlostanova argues that "societies are offered certain sanctioned forms of constructed collective memory which does not conserve but rather erases the past which is still full of restless ghosts... The victims are forced to forgive and forget," and this colonization of memory "fixes rapture in the texture of memory connected with violence, trauma, and humiliation" (Tlostanova, 2014: 64).

Significantly, however, the act of speaking itself for Dina becomes a powerful mechanism for overriding the colonial experience. Regaining the ability to speak, unmuting her voice and releasing the pain are signs of the beginning of the healing process, and the possibility of transcending the traumas associated with various 
repressions of colonialist regimes, which ultimately opens up the opportunity for the colonials to build their world anew. Thus, The Road Home advocates a cultural history that while looking backward to the past also points forward to the future and to ways for the reexistence and (trans)formation of one's culture and identity. Transition or transformation is a process of reiteration, of remembering history, but in such a way that the repetition recognizes the differences within and thus gradually reforms traditional forms and relationships between the oppressors and the oppressed. Ultimately, the goal is to reach that level of identity and identification that would allow the Circassian community both to immortalize their history of pain and suffering and to celebrate memory as the most precious tool against forgetfulness and erasure.

\section{3. "I Am the Face of the New Circassian Identity:" Transnationality and the Construction of Circassian Selves.}

The Road Home is not merely a geographical journey, but first and foremost a spiritual one, one that reconnects Dina with her family's and nation's history, her culture, and her roots. It demonstrates that for a (post)colonial subject, a renewed sense of self lies in a deeper understanding of one's historical roots. It also advocates the necessity to recognize and resist the multiple imperial discourses that were imposed on the subjectivities of these people. Quite early in the novel, Arma's character exclaims: "I am the face of the new Circassian identity, although marginal yet" (Arma, 59) acknowledging her heterogeneous identity of multiple crossings (linguistic, geographical, cultural) and her position as a colonial gendered intellectual who attempts to negotiate her identity between and beyond the existing power structures. This position allows her to reassess and to reevaluate her identity by pointing out the distortions in the colonial representations of Circassian women. Over-determined by stereotypes and clichés that tended to simplify their identities, these representations deprived women of agency and reduced them to the level of possessions:

I see my image reflected a thousand times in the stream of people, and it disintegrates into a multitude of NOT MINE portraits. From my 
round, multi-colored personality that sparkles with all its multifaceted edges... they want to make a flat pattern, a diagram. It conceals all colors and shades of the world, but they try to paint it only black and white. They take off my real dress that resembles the white wedding dress that was cut out and sewn carefully by my mother and tear it into pieces by pulling it into different directions, and then devour them. They put on me an old, alien dress that better reflects the taste of the appraiser because it resembles the dress of an odalisque woman. They put my body on a hard and narrow bed and cut off all the abundant waves overflowing its borders. With confidence, they put me into a stiff cage, so they could better "see and study" me, and they put a fixed price on my hip. They search for me among different things: scientific charts and tables, statistics, information and plans, and various other laws and rules. They apply to me their laughable frames fully convinced that they are mine. My world, which is a boundless ocean, they call a dirty puddle (Arma, 350, emphasis in the original).

Arma is concerned with the effects that multiple discourses have had on the lives and identities of Circassian women. By erasing their agency, diversity, resistance, thinking, and voices, these discourses produced a twisted female consciousness that has been devastated by multiple alterations. Arma's goal is to recover the self that is buried under multiple layers of distortions and imposed identities:

I have an infinite number of names and faces. I slip through the cracks between the mirrors and find myself beyond the looking glass at home, where my real self lives...

My real self is contained in the sounds of ancient shikapshina that awaken the most inner layers of my soul; it is in the eternal whirling of red-furred foxes in the virgin mountain forests; and in the moonlight of white bones of unidentified dolmens that resemble a woman's bosom. My self is to be found in the clear sounds of a tambourine that streams through the forests, cliffs, and valleys of my boundless soul - of my homeland -- and cannot find limits even on the sparkling summits overhang by the angel's wings... it is found in the dark blood drops that begin their ancestral line from the shimmering corpuscles of black holes from the pre-universe (Arma, 351, emphasis in the original). 
As seen from these excerpts, the emancipated sense of self is able to reflect on her reflections; she dares to look at her image(s), and is no longer 'captured' or 'caught up' by those still and frozen projections. She escapes them by "slipping through" them; and once she is beyond them, on the other side of the looking glass, she is able to produce her own self-projections. She replaces the frozen images with a new fluid, shifting subjectivity that is open-ended. Her new self-image grounded in the local logic, cosmology, and epistemology, is closely related to the notions of cosmos, of country, of home; they are, in fact, seen as inseparable from each other and become the source of spiritual and regenerative power. Dina searches for her own identity in her native places and she chooses the irrational ways of construction of her new self.

Counteracting objectified portrayals of Circassian women in Western/Russian colonial discourses and historiography, ${ }^{12}$ Arma creates female characters who not only speak up in their own voices, but ultimately present a female consciousness that seizes discursive control of their (hi)stories. She offers simultaneously a deconstructive and reconstructive vision of identities. By challenging the received concepts and notions of the female, of native Circassian women, and particularly the notion of submissiveness that has marked so much of colonial literature and the literary canon, Arma has articulated woman's most basic right - her right to control her own body and mind. She is not reproducing so much as producing and forging a new subjectivity, a new cultural identity, a new self that is multiple and tangible. The open-endedness of her new constructed subjectivity is associated with a fluid, transformational thinking process that breaks down the rigid boundaries of conventional social and symbolic structures. Arma is writing from the position of the border, indeed from the "open wound"13 position.

According to Anzaldúa, this position at the border is also unique, because it is a position from which the "official" reality of the rational, "the consciousness of duality" or "white rationality" could be challenged and "the other mode of consciousness" that facilitates "images from the soul and the unconscious through dreams and the imagination" inaugurated (Anzaldúa, 59). Addressing the reliance of Western modernity on rationality and reason, including the tendency 
of contemporary Western scholars to "study" the natives, Anzaldúa writes: "In trying to become 'objective,' Western culture made 'objects' of things and people when it distanced itself from them, thereby losing 'touch' with them. This dichotomy is the root of all violence" (Anzaldúa, 59). Then, describing the border identities of the india and the mestiza, Anzaldúa continues: "Not only was the brain split into two functions but so was reality. Thus people who inhabit both realities are forced to live in the interface between the two, forced to become adept at switching modes" (Anzaldúa, 59). Anzaldúa concludes her essay with a statement:

The future will belong to the mestiza. Because the future depends on the breaking down of paradigms, it depends on straddling of two or more cultures. By creating a new mythos - that is, a change in the way we perceive reality, the way we see ourselves, and the way we behave - la mestiza creates a new consciousness (Anzaldúa, 102).

It echoes the reconceptualization of the trickster problematic in the works of transnational feminist theorists such as Chela Sandoval, Maria Lugones, and Madina Tlostanova (discussed earlier). In the Methodology of the Oppressed (2000), Chela Sandoval argues that a "differential mode of consciousness" is needed, in order to transcend the dominant power structures. The "differential practitioner," in that case, needs to have a "commitment to the process of metamorphosis itself: this is the activity of the trickster who practices subjectivity as masquerade," which is done not solely for survival purposes anymore (Sandoval, 60-62). Maria Lugones adds the idea of "playfulness" that underlines this new consciousness: "We are not self-important, we are not fixed in particular constructions of ourselves, which is part of saying that we are open to self-construction... While playful, we have not abandoned ourselves to, nor are we stuck in, any particular 'world.' We are there creatively" (Lugones, 1987: 16). All these women writers emphasize the flexibility and the nonrestrictive nature of borderland subjectivity and its potential for transformative thinking and the alternative ways of knowing and shaping reality.

The "insertion" of Circassian women in history, the recovering of their histories is seen in fiction, as well as non-fiction literature. In her article "Prehistories of Globalization: Circassian Identity in Motion" 
(Shami, 2000), the diasporic Circassian anthropologist Seteney Shami attempts to bring Circassian voices to the historical forefront by presenting the narratives of two journeys undertaken by two Circassian women - Shengul's journey from Turkey to her homeland in the Caucasus in $1993^{14}$ and Shemsigul's journey from the Caucasus to slavery in $1854^{15}$ - articulating what these two women thought and felt about their experiences. By becoming a testimony of voices never heard, these narratives constitute a counter history to the dominant historical narratives of Ottoman slavery and the construction of Circassian identidties. As she chronicles these Circassian experiences, Shami presents Circassian female identities marked by motion and transformation (Shami, 2000). Shami analyzes Shengul's narrative (an interview conducted in the 1990s) and compares it to Shemsigul's story from 1850s (Toledano, 1993), and discovers the unexpected divergence and convergences in the "changing trajectories of migration, memory, and imagination" (Shami, 2000: 178). Shemsigul's story framed by Shami as a "prehistory to globalization" throws light on how the past or the history (in this case an erased history) of Circassians acts upon their present engagements with globality and the ways in which they experience their newly accessible homeland in the Caucasus. According to Shami, these stories reveal that, "mobility and migration emerge clearly as constitutive elements of Circassian identity" (Shami, 2000: 178).

Shami further investigates the implications of the relationship between globalization and culture, using as an example the experiences of the Circassian diaspora communities. Examining the process of construction of Circassian identities in the post-Soviet era and in the context of globalization and shifting or disappearing borders, Shami demonstrates the fluidity and the ambiguity of this process that challenges both the concepts of ethnicity and nationalism that previously has been regarded as monolithic constructs. The construction of Circassian identities, she argues, is based on the transcendence of national boundaries and on the emergence of transnational bonds and identities. After the breakup of the Soviet Union, an increasing number of Circassians from diaspora traveled to their homeland in the Caucasus, some as visitors, and others were intending to settle there permanently. Straddling two or 
more places and building bridges between them, these diasporic individuals embody transnational identity, and the culture of transnationalism - the Caucasus emerges as a place where these transnational encounters occur, and where new economic and political organizations are formed (Shami, 2000).

In her article "Circassian Encounters: The Self as Other and the Production of the Homeland in the North Caucasus" (1998), Shami examines the concepts of home and identity through the narratives of several diasporic individuals who journeyed from Turkey to their homeland in the Caucasus. Capturing the intricacies of "identities in motion" these narratives represent histories of movement that complicate the notions of home and exile, of self and other, and are directly related to the long history of displacements that formed and transformed Circassian identities. Circassians living both in homeland and in diaspora went through painful but ultimately transformational interaction with and adaptation to, different cultures. As these narratives demonstrate, for most returnees to the Caucasus, encountering their ancestral home has an unsettling effect. Once they experience the discrepancy between the reality and their imagined homeland, it produces a feeling "of shock, of non-recognition, and the encounter of the "self as other" (Shami, 1998: 629). But despite the many contradictions that characterize Circassian diaspora-homeland and intra-diasporic encounters, Circassian transnationalism continues to evolve around a shared set of values and goals, including the preservation of culture, particularly of language that have been in consistent decline, and the struggle for self-determination. Both Shami and Arma discuss the precariousness of Circassian identities resulting from their experiences living in the homeland and in diaspora and how the "road home" or the journey to identity is a problematic process, but also an exciting one, as it exposes in the process a complex, textured and polyvalent Circassian identity and Circassian society in a condition of open-ended transition. 


\section{NOTES}

${ }^{1}$ On the history of Russian colonization of the North Caucasus see: Daniel R Brower and Edward J. Lazzerini (1997); Austin Jersild (2002); Charles King (2008); Walter Richmond (2008).

${ }^{2}$ See, for a example, the literary works of Mikhail Adzhuk-Girei (Lokhvitsky) (1991); Mukhadin Quandour (1996-97); Dzhambulat Koshubaev (1999); Nalbi Kuek (2002); Mukhamed Emkuzhev (2009); Mukhamed Adzinov (2010).

${ }^{3}$ See, for example, Dina Damian (2006).

${ }^{4}$ Bill Ashcroft, Gareth Griffiths, and Helen Tiffin (2002), p. 9.

${ }^{5}$ According to Tekueva, the god of forest Mazitkha was initially a female deity. In her book, Tekueva quotes the epos Narts, in which Sataney, the great mother of all Narts, is addressed as Mazitkha, the goddess of forest, representing thus the crucial link with the forest as a symbol of life (Tekueva, 2006: 10). Elaborating Tekueva's point, Tlostanova takes it further and argues that Mazitkha "acts both in its male and female forms and only in the later written distorted versions...it acquires a distinctly masculine image" (Tlostanova, 2010: 164-165). As Circassians came under the influence of more male-dominated religions, first the Christianity, and later Islam, the indigenous faith was slowly abandoned, and the powerful female deities were substituted with male god(s).

${ }^{6}$ An indigenous pre-Christian and pre-Islamic deity that was "not perceived as above the world or outside it, but rather as an integral part of it along with people, nature, and other supreme beings" (quoted in Tlostanova 2010: 163).

7 Recently, a small but steadily growing number of Circassians (mostly younger generation) started to revive the ancient Circassian an' $m^{\prime}$ traditions and the worship of old spirit entities and their supernatural powers, turning this process into the symbol of spiritual, political, and psychological rebirth.,

${ }^{8}$ The assimilationist language policy continues even today causing political and cultural damages to all sides and creating alienation between them. The non-Russian ethnic groups, however, are more vulnerable, as they have lately undergone significant decrease in terms of their rights to develop their languages. On the discriminatory non-Russian language policies of the Soviet/Russian states, see Zhemukhov \& Aktürk (2015).

${ }^{9}$ The latest publications that directly address the question of genocide with respect to the Russian treatment of Circassians in the nineteenth century include Maja Catic (2015); Walter Richmond (2008) and (2013); Irma Kreiten (2009), and Stephen Shenfield (1999).

${ }^{10}$ The rhetoric of the "empty lands" is still maintained on the highest official levels of Russian administration. Veneamin Kondratiev, who has been appointed as the governor of Krasnodar Krai (a federal subject in Russia 
located on the territory of historical Western Circassia) repeated the same imperialist rhetoric in his inauguration speech in September 2015. While emphasizing "fighting the corruption" and "respecting the laws" as his priority, Kondratiev stated: "The legal system in the Krasnodar Territory must become more effective. This is the only way we can achieve the significant economic growth and social development, and also help our citizens to realize their entrepreneurial initiatives... This is the only way we can ensure people a decent life today, not in the distant future. Yes, this path is challenging and not for the weak. But that is exactly how the history of our Kuban region began 223 years ago, when the Cossacks landed in the barren steppe, and turned it into blossoming orchards and fertile lands" (Inauguration Speech, my emphasis; available at: http://admkrai.krasnodar.ru/content/14/show/292010/, accessed on 2 February 2016).

11 The Caucasian War is the officially accepted in Russian/Soviet historiography definition of the military colonization of the Caucasus. The Circassian narratives favor the more specific terms such as Russo-Caucasian War emphasizing the resistance of all Caucasians (Circassians, Chechens, Daghestanies, and others) to the Russian colonization of their lands, or the Russo-Circassian War (1763-1864) highlighting the long resistance of Circassians to the Russian imperial project.

${ }^{12}$ A few such examples are: Voltaire (1733); Ditson, G. L. (1850); Murray Ballou, (1851); Byron (1824); Aleksandr Pushkin (1821); and Mikhail Lermontov (1841). The process of recycling of old imagery and myths became central to the contemporary Circassian nationalistic discourses. On the centrality of the image of Circassian beauty to the gendered constructions of homeland and diasporic identities, see: Khasan Sukunov and Irina Sukunova (1992) and Setenay Nil Doğan (2010).

${ }^{13}$ The term is coined by Gloria Anzaldúa in her book Borderlands/La Frontera: The New Mestiza (1999).

${ }^{14}$ Shami presents an ethnographic text narrating a journey undertaken by a Circassian woman in 1993 from diaspora to homeland, from Turkey to the Caucasus. Shengul was one of the first "returnees" to the Caucasus, to her historic homeland that became accessible after the collapse of the Soviet Union.

${ }^{15}$ This is a historical text dating from 1854 and documenting the journey of the Circassian woman from homeland to slavery, from the Caucasus to Constantinople, and then to Cairo. The story of Shemsigul was first reconstructed by Ehud Toledano, using the available documents of the police interrogation (Toledano 1993). 


\section{BIBLIOGRAPHY}

Adzhuk-Girei (Lokhvitsky), M. (1991), Poiski bogov (In Search of Gods), Merani: Tbilisi.

Adzinov, M. (2010), Na beregakh moei pechali (On the Shores of My Sorrow). GP KBR "Respublikasnkii Poligrafkombinat im, Revolutsii 1905 g.: Nalchik.

Anzaldúa, G. (1999), Borderlands/La Frontera: The New Mestiza, Aunt Lute Books: San Francisco.

Arma, D. (2009), Doroga Domoi (The Road Home), Elbrus: Nalchik.

Ashcroft, B., Griffiths, G., Tiffin, H. (2002), The Empire Writes Back: Theory and Practice in Post-Colonial Literature, Routledge: New York.

Azouqa, A. O. (2004), The Circassians in the Imperial Discourse of Pushkin, Lermontov, and Tolstoy, Amman: Publications of Deanship of Academic Research of University of Jordan.

Brower, D R., Lazzerini E. J. (1997), Russia's Orient: Imperial Borderlands and Peoples, 1700-1917, Indiana University Press: Bloomington.

Byron, G. G. (1967), Don Juan. Cantos I-IV, Routledge \& K. Paul: London.

Catic, M. (2015), "Circassians and the Politics of Genocide Recognition", Europe-Asia Studies, 67/10, 1685-1708.

Damian, D. (2006), V Vashem mire ya-prokhozhii (I Am a Stranger in Your World), KomKniga: Moscow.

Ditson, G. L. (1850), Circassia; Or, A Tour to the Caucasus, Stringer \& Townsend: New York.

Doğan, S. N. (2010), "From National Humiliation to Difference: The image of the Circassian Beauty in the Discourses of Circassian Diaspora Nationalists", New Perspectives on Turkey, 42, 77-102.

Emkuzhev, M. (2009), Noch Kaddar (Kaddar Night), Nezavisimoe Izdatel'stvo "Pik": Moscow.

Jersild, A. (2002), Orientalism and Empire: North Caucasus Mountain Peoples and the Georgian Frontier, 1845-1917, McGill-Queen's University Press: Montreal \& Ithaca.

Quandour, M. (1996-97), Kavkaz (The Caucasus: A Trilogy), Izdatelskii Centre Elfa: Nalchik.

Keating, A. L. (1996), Women Reading Women Writing: Self-Invention in Paula Gunn Allen, Gloria Anzaldúa, and Audre Lorde, Temple University Press: Philadelphia.

King, C. (2008), The Ghost of Freedom: A History of the Caucasus, Oxford University Press: Oxford \& New York. 
Koshubaev, D. (1999), Abrag (Abrag), Elbrus: Nalchik.

Kreiten, I. (2009), "A Colonial Experiment in Cleansing: The Russian Conquest of the Western Caucasus, 1856-65", Journal of Genocide Research, $11 / 2-3,213-241$.

Kuek, N. (2002), Vino Mertvykh (Vine of the Dead), Maikop.

Layton, S. (1994), Russian Literature and Empire: Conquest of the Caucasus from Pushkin to Tolstoi, Cambridge University Press: Cambridge.

Lermontov, M. (2013), A Hero of Our Time, Trans. by Slater, N. P., Oxford University Press: Oxford.

Lugones, M. (1987), "Playfulness, "World"- Travelling, and Loving Perception", Hypatia, 2/2, 3-19.

Moore, D. C. (2001), "Is the Post- in Postcolonial the Post- in Post-Soviet? Toward a Global Postcolonial Critique", PMLA, 116/1, 111-128.

Murray-Ballou, M. (2006), The Circassian Slave, or, the Sultan's Favorite, Dodo Press: Gloucester, UK.

Pushkin, A. S. (1962-1966), Polnoe sobranie sochineni v desyati tomakh, 10 vols, Izdatel'stvo Akademii nauk SSSR: Moscow.

Rich, A. (1972), "When We Dead Awaken: Writing as Re-Vision", College English, 34/1, 18-30.

Richmond, W. (2008), The Northwest Caucasus: Past, Present, Future, Routledge: London \& New York.

. (2013), The Circassian Genocide, Rutgers University Press: New Brunswick, New Jersey and London.

Shami, S. (1998), "Circassian Encounters: The Self as Other and the Production of the Homeland in the North Caucasus", Development \& Change, 29, 4/10, 617- 646 .

(2000), "Prehistories of Globalization: Circassian Identity in Motion" Public Culture, 12, 1/01, 177-204.

Sukunov, K., Sukunova, I. (1992), Cherkeshenka (The Circassian Woman), RIPO: Maikop.

Tekueva, M. A. (2006), Muzhchina i Zhenshchina v Adygskol kul'ture: Traditsii i Sovremennost' (Man and Woman in Circassian Culture: Tradition and Modernity), Nalchik: GP KBR "Respublikanskil poligrafkombinat im. Revoliutsii 1905: Ėl'-Fa.

Tlostanova, M. V. (2010), Gender Epistemologies and Eurasian Borderlands, Palgrave Macmillan: New York.

(2014), "Coloniality of Memory: violence-traumarepentance-revenge in postdependence narratives", Jazyk, Slovesnost, Kultura (Language, Philology, Culture), 5, 63-87. 
Toledano, E.R. (2006), "Shemsigul: A Circassian Slave in Mid-Nineteenth Century Cairo", Struggle and Survival in the Modern Middle East, Edmund Burke, III and David N. Yaghoubian (eds.), University of California Press: Berkeley, Los Angeles and London, 59-74.

Voltaire. (2003), Philosophical Letters: Letters Concerning the English Nation, Dover Publications: Mineola \& New York.

Zhemukhov, S., Aktürk, Ş. (2015), "The Movement Toward a Monolingual Nation in Russia: The Language Policy in the Circassian Republics of the Northern Caucasus", Journal of Caucasian Studies, 1/1, 35-71. 
